\title{
Calibrating neighbourhood preferences in the land value contour model
}

\author{
Sanjeev Kumar* and Krishna Kumar Dhote \\ Department of Architecture and Planning, Maulana Azad National Institute of Technology, Bhopal 462 003, India
}

\begin{abstract}
Neighbourhood is a spatial self-contained residential colony maintaining effective socio-economic control within a city. The study presumes that people's preference for residential location and choice of facilities might be a robust predictor of their neighbourhood demand. Their preferences reflect in terms of land value. GIS-based spatial contour model was used to examine whether the effect of residential preferences varied in terms of residential land value. The study found significant variations in residents' preferences for accessible facilities in a city. The finding reveals that preferences for residential choice depend on many factors. Residents are willing to pay for easily accessible facilities which could be observed in the residential land value contour model of GIS.
\end{abstract}

Keywords: Accessible facilities, contour model, neighbourhood preferences, residential land value.

LAND is one of the essential needs on earth for all living beings. Human beings require land for living, working and many other socio-economic activities, either directly or indirectly ${ }^{1}$. Urbanization drives urban sprawl, and pushes up the value of land and the cost of service delivery for $\mathrm{all}^{2}$. Urbanization rate indicates the fact that the population is growing at a fast pace; therefore, demand for residential land would be more in and around urban centres. Due to limited availability of such land within urban areas, land value is scaling new heights rapidly causing property values to increase beyond logical limits in both residential and commercial segments. Land value is affected by demand factors, such as views, amenities, proximity to facilities, transport, etc. ${ }^{3}$. Knowledge of the factors affecting land value is an important advantage in identifying the future of urban development and anticipating probable changes.

The land value is a function of various physical, environmental and psychological factors in an urban area. Since the value of land is unique, it is often difficult to identify the appropriate factors that might explain different land values. Land is a heterogeneous good that is comprised of a bundle of unique features reflecting not only its location, but also other facilities and amenities such as quality of the neighbourhood and infrastructure ${ }^{4}$.

\footnotetext{
*For correspondence. (e-mail: sanju.spa@gmail.com)
}

Understanding of the factors influencing residential land value would enable policymakers to allocate more efficient residential land use. It also helps local governments and private utility providers in decision-making to monitor new developments and activities in the land market to build a complementary infrastructure for development. The spatial land value model would rationalize the valuation approach for different locations. It would be helpful in land-use proposals, real estate growth estimation, and improvement of government revenue. Thus, there is a need to work on land value and explore its spatial morphology. In-migration over the last decades has increased the demand for residential land in urban areas. Unfortunately, access to land via the government functionary has not kept pace with demand. The selection of land for residential purposes is dependent on its location and other allied benefits. The present study, therefore, seeks to unravel the main factors influencing residential land value, and their explanatory spatial and non-spatial determinants in residential land value estimation.

\section{Research objective and methodology}

A literature review shows factors having impact on urban residential land value. Empirical studies on urban land value have worked on various functions with spatial and non-spatial determinants. After understanding the role of urban facilities for neighbourhood preferences, this study examines the relationship between these facilities and their land value morphology. Therefore, the objective of the study is to calibrate neighbourhood preferences in an urban residential land value contour model. The smallest planning unit below 5000 population is conceived as a housing area. The hierarchy of urban development defines neighbourhood as a housing cluster for population of 5000-15,000 with minimum infrastructure provision. This study analyses the relationship between residential land value and identified six urban facilities functioning as factors for land value establishment. First, we show that ways in which neighbourhoods are perceived and how residents have widely differing demands regarding the extent and distinctive facilities for their own neighbourhood, with the case example of Bhopal city, Madhya Pradesh (MP), India. Second, we highlight the importance of facilities in structuring residential land 
value, which is the reflection of neighbourhood preferences. We conclude with suggestions as to how neighbourhood demands might be incorporated into the urban residential land value contour model.

Land value data of residential colonies published by the District Collector were collected to assess residential land value morphology for Bhopal city. This value is also known as Circle Rate, which might be different from the market rate for some locations. Collector value is the statutory published unit value of land and buildings of different uses. It was observed that only access to arterial roads had been accounted for in the premium on land values. The study identifies six factors responsible for the determination of residential land value and follows an approach to explore the relative contribution of these factors on residential land value of Bhopal city. Priorities of recent buyers from all municipal zones were identified for the six factors during selection of residential land. This was a significant phase, involving consensus building among buyers' perceptions to find their combined opinion. Land values of all 3111 urban residential colonies of Bhopal, which were listed in the published Collector land value sheet of 2019-20 were considered. The land value date were synthesized into the attribute table of Geographic Information System (GIS). Spatial analysis was performed using ArcMap 10.1 GIS software. Satellite images were collected from Google Earth at $500 \mathrm{~m}$ elevation to identify the location of residential colonies and facilities. These images were geo-referenced in WGS_1984_UTM_Zone_43N projected coordinate system; Transverse_Mercator projection; GCS_WGS_1984 Geographic Coordinate System; D_WGS_1984 Datum; Greenwich Prime Meridian and Degree Angular Unit. The relationship between residential land values of colonies was measured separately with each identified factor. The study examined the influence of different factors in terms of their range and threshold. A land value contour model was prepared in GIS, which could be useful to examine the residential land value morphology around the identified factors. We studied the significant role of the contour model in urban land value assessment. The spatial pattern of residential land value in urban areas could be elaborated with the proposed model.

\section{Bhopal city}

Bhopal city is located on the hilly terrain in central India (Figure 1). National and State Highways link this city to many large cities of the country. Bhopal is connected by the broad gauge railway line to other metros and is also served by regular air services to Mumbai, Delhi and Indore $^{5}$. Bhopal city is a fascinating amalgam of scenic beauty, old historic sites, educational and modern urban planning. It is the administrative and political nerve centre of MP. Nestled among lakes and hills, it is sur- rounded by forests and poor agricultural land. The city has more than 1.8 million population and covers an area of 285.9 sq. $\mathrm{km}$.

Development in Bhopal and surrounding areas has been rapid since the last decade. The city grew mostly in the southeast direction along the national highway 46 . Not only the central area of the municipal boundary of Bhopal, but also its hinterland are considered prime residential areas. The natural diversity and greenery of the city attract migrants. These migrants increase population growth which requires additional land for their living. The rise in demand for land resulted in a rise in land value. Rapid development also accelerated the urbanization process yielding the growth rate of economic investments, trade and industry. Bhopal was notified as having the second most dynamic residential value in Residex for 2011 by the National Housing Bank of India. The city has been continuously listed in the top ten cities of Residex till 2019. The cost of residential buildings has recorded a maximum increase, indicating that Bhopal is fast emerging as one of the major residential real estate investment hubs in the country.

Bhopal is divided into 14 zones, which are further subdivided into 70 wards. The city has four distinct townships: BHEL Township, T.T. Nagar, Bairagarh and Fringe Area Development, surrounding the old city and its peripheral areas. The areas between these four townships are moderately inhabited. The existing core of the city and its surroundings is the hub of all activities and is the most congested area. The central area has a uniform skyline and forms a confined residential neighbourhood. Authorized residential colonies located within the municipal area are well connected with prominent city-level amenities. The economic class of inhabitants could be identified with their housing typologies in a neighbourhood. The inner city neighbourhoods have a majority of Muslim population, while the Hindu community lives in new Bhopal and the outskirts. The planned residential colonies have demarcated public and open spaces. On the other hand, unauthorized colonies are lacking neighbourhood-level facilities. Land values of colonies which are away from the city core and lack basic urban services are found to decrease.

\section{Literature review}

Modern studies on the impacts of agglomeration in urban centres and of the value of new infrastructure provision apply land values to measure the benefits of a certain feature, be it an infrastructure project or spillover induced by proximity to other firms, markets and workers ${ }^{6}$. Land values are associated with many factors, not only environmental conditions but also government policies and factors of socio-economic value ${ }^{7}$. These factors have been explored in many studies and their impacts elaborated using 


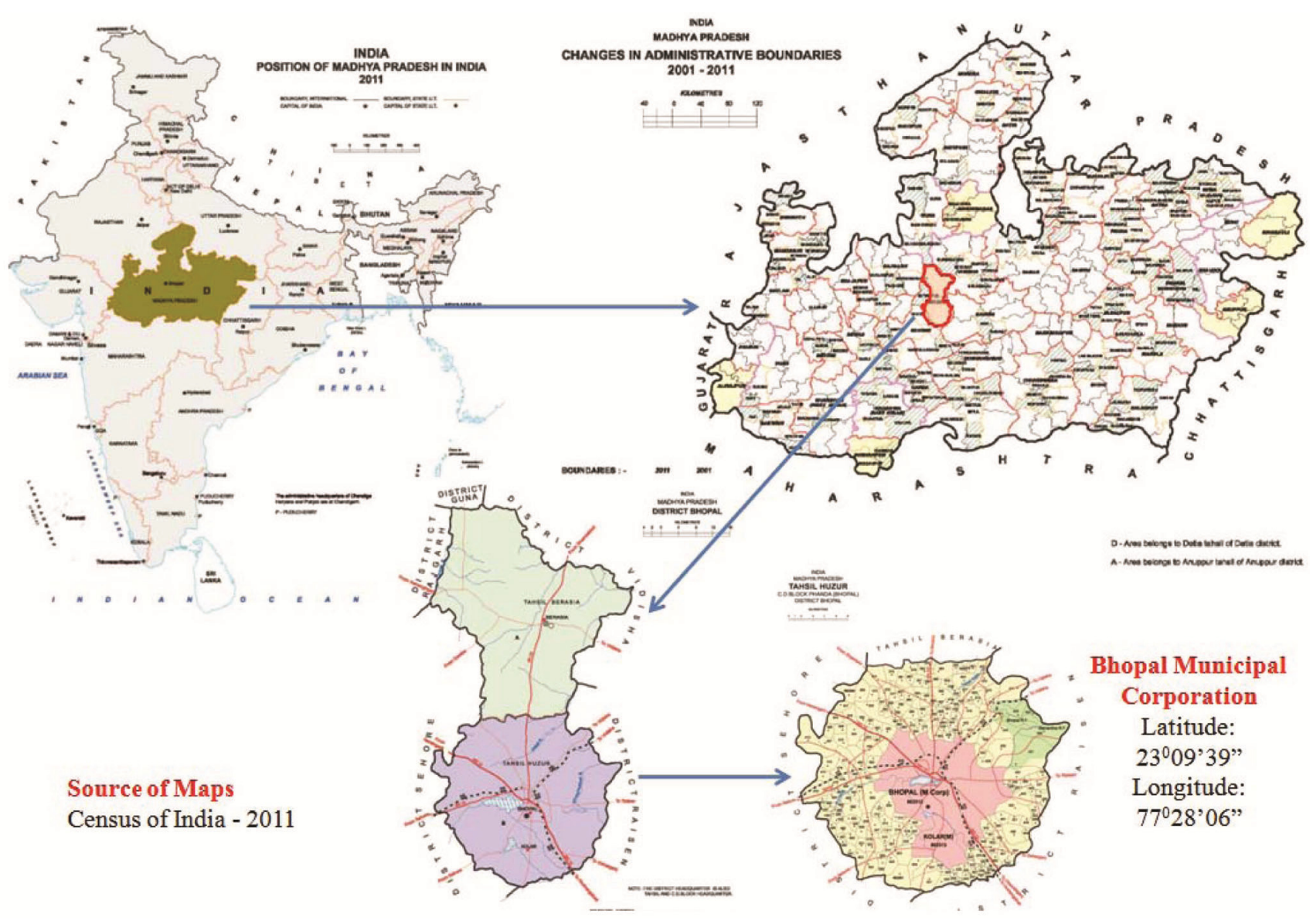

Figure 1. Location map of Bhopal city, Madhya Pradesh, India.

different tools and techniques. Due to the importance of land in the overall welfare of any nation, change in landvalue pattern has engaged the attention of both academic and professional communities over the last 30 years, notably in the UK, USA and Australia ${ }^{8}$. Extensive studies have been carried out on the various determinants of land values.

Dutt and $\mathrm{Khan}^{9}$ analysed the spatial pattern of land values in Akron, USA, in relation to the general land-use situation, and to identify the major factors influencing land values in the city considering lot size, building value and distance from the central business district (CBD) as land-value determinants. Competitive bidding for land determines the urban land-use pattern ${ }^{10}$. In the long run, this competitive allocation process results in a tendency for the overall land-use pattern to adjust, so that each location is occupied by the activity which can pay the highest rent ${ }^{11}$. A location has its potential utility for each type of activity which could be measured by willingness to pay rent for the use of a location ${ }^{12}$. Neoclassical marginalist models implicitly assume that every land has its specific requirement of location depending upon the activities. The land uses which demands proximity to the centre of the city or away from the city will bid high for the land required for a specific activity ${ }^{13}$. The Burgess ${ }^{10}$ model provides a degree of explanation of a bid-rent theory which was derived from empirical observations on the way in which the city of Chicago, in USA had developed. As such, it is a hybrid of idealized land-use patterns and urban social structure with a strong emphasis upon residential areas. Hoyt ${ }^{10}$ in a study of American cities on rent levels of residential areas reveals the importance of sector form of development. The main difference between the Hoyt and Burgess models is that the former considered direction as well as distance from the CBD to be important in determining land use. Harris and Ullman ${ }^{10}$ extended Hoyt's subtle recognition that the CBD was not the only focus of activities, and made it explicit in their multiple nuclei model. It implies that a city has a cellular structure within which several specialized areas develop ${ }^{10}$. The diagrammatic model of Mann draws heavily upon the concentric zone and sector models, but it makes passing reference to separate and more specialized $\operatorname{areas}^{13}$.

The uneven distribution of land values has attracted numerous studies as dynamic urban development has continuously challenged the understanding of the pattern of land-value distribution and the determinants underlying these patterns. In the early 20th century Chicago, $75 \%$ 


\section{RESEARCH ARTICLES}

of land value variations was explained by the distance variables alone. In the $1960 \mathrm{~s}$, however, distance variables could only explain $10 \%$ of the land value variation in Chicago ${ }^{14}$. According to Miller and Geltner ${ }^{15}$, real-world cities are not purely monocentric; they have other major activity areas besides the CBD. Large cities are sprinkled with neighbourhood business districts (NBDs) that serve the needs of local communities. The distance variable alone explained $62 \%$ of the variations, while addition of the other two variables only increased the explanatory power to about $69 \%$ (ref. 15). Recently, more scientific as well as financial analyses have been carried out to establish more relevant factors controlling land value, other than distance to the city centre. Land value around nodes, inter-state access points or light rail stops increases the most as long as zoning and other land-use regulations permit more intensive development around such sites ${ }^{16}$. It was reported that the actual residential land value function can exhibit complex curvilinear shapes ${ }^{13}$, and hence land values may not automatically decline with distance from the CBD alone.

The land value function is dependent on many factors which help in the mapping of land value. Many studies have discussed several factors having an impact on land values. The relationship between transport service and property values in Enugu, Nigeria, was studied in 2002, while the negative impact of waste dump sites on rental values of residential properties was assessed in 2007 (refs 17, 18). Kauko ${ }^{19}$, Dowell and Monkkonen ${ }^{24}$ assessed urban land market behaviour with respect to distance from facilities. Morandé et al., shed light on variables that drive vacant land in Santiago, Chile. Oduwaye examined the spatial variation of residential land value in Lagos Metropolis, Nigeria, with the accessibility of neighbourhood facilities. Tamba et al. examined neighbourhood factors for their impacts on urban land value in Freetown, Sinerra Leone. Saefuddin et $a l .^{7}$ prepare a land value model based on spatial determinants for the case of South Tangerang, Indonesia ${ }^{7}$. Uju and Iyanda ${ }^{23}$ did comparative analysis among 21 spatial and non-spatial determinants with residential land value. Emoh et $a l^{8}$ examined various determinants of residential land value in Onitsha, Nigeria. Studies have listed a set of factors that have been commonly used in property valuation research $^{7,8,19-23}$. These factors are social, physical, economic and environmental ${ }^{19-22}$. The impact of regulatory provisions and allied taxes for residential development on land value has also been explained ${ }^{7,8,19,20,24}$. The impact of factors on residential land has been statistically mapped in terms of their accessibility ${ }^{7,8,17,19-26}$. Based on the literature review considering different nations, six factors having an impact on residential land value have been identified (Table 1).

Environmental and social characteristics, public facilities and related infrastructure are often used as the explanatory variables in land-value models. A study of the land-value model shows that the coefficients of these factors varied from place to place. The most influential factors were distance from the highway, arterial road and public facilities. The study of residential land value is significant with respect to its spatial variation. There are tremendous research opportunities regarding factors of residential land value determinants.

Earlier studies found the relationship between land value and its factors using statistical methods. Since the early 20th century, three approaches to estimate the market value of properties have been refined through the years and variations developed for specific appraisal problems ${ }^{27}$. These property value estimation approaches are: (i) sales comparison approach; (ii) cost approach, and (iii) income approach. To analyse the land value data, statistical approaches such as regression models are useful for cases having influencing factors on land value. Other studies highlighted ordinary least square (OLS) regression lacking the ability to consider spatial effects, which then led to biased and inefficient estimations ${ }^{28}$. Geographically weighted regression (GWR) provides an alternative approach for analysing spatial data, including land values $^{7}$. Spatial effects could be highlighted through different analysis techniques of the GIS tool. Accessibility and proximity level are over analysed through travel-time thresholds with the use of a distance decay function.

The literature review shows that spatial as well as nonspatial factors determine land value. Some determinants are significant at the city level, while others function well

Table 1. Factors influencing residential land value

\begin{tabular}{|c|c|}
\hline $\begin{array}{l}\text { Factors } \\
\text { identified }\end{array}$ & Source of identified factors \\
\hline Airport & $\begin{array}{l}\text { Bhargava (2013), Goffette-Nagot et al. }(2009)^{29} \text {, } \\
\text { Kauko (2003), Olayiwola et al. }(2006)\end{array}$ \\
\hline Bus stops & $\begin{array}{l}\text { Bhargava (2013), Emoh et al. (2013), Goffette- } \\
\text { Nagot et al. (2009), Kauko (2003), Oduwaye (2009), } \\
\text { Ogbuefi and Egbenta (2002), Olayiwola et al. } \\
\text { (2006), Tamba et al. (2011) }\end{array}$ \\
\hline Hospitals & $\begin{array}{l}\text { Dowall and Monkkonen (2007), Emoh et al. (2013), } \\
\text { Kauko (2003), Oduwaye (2009), Ogbuefi and } \\
\text { Egbenta (2002), Olayiwola et al. (2006), Saefuddin } \\
\text { et al. (2012), Tamba et al. (2011), Uju and Iyanda } \\
\text { (2012) }\end{array}$ \\
\hline Malls & $\begin{array}{l}\text { Bhargava (2013), Dowall and Monkkonen (2007), } \\
\text { Emoh et al. (2013), Goffette-Nagot et al. (2009), } \\
\text { Kauko (2003), Olayiwola et al. (2006), Saefuddin } \\
\text { et al. (2012), Uju and Iyanda (2012) }\end{array}$ \\
\hline Railway station & $\begin{array}{l}\text { Bhargava (2013), Emoh et al. (2013), Kauko (2003), } \\
\text { Morandé et al. (2008), Olayiwola et al. (2006) }\end{array}$ \\
\hline Schools & $\begin{array}{l}\text { Bhargava (2013), Dowall and Monkkonen (2007), } \\
\text { Emoh et al. (2013), Goffette-Nagot et al. (2009), } \\
\text { Kauko (2003), Morandé et al. (2008), Oduwaye } \\
\text { (2009), Ogbuefi and Egbenta (2002), Olayiwola et } \\
\text { al. (2006), Saefuddin et al. (2012), Tamba et al. } \\
\text { (2011), Uju and Iyanda (2012) }\end{array}$ \\
\hline
\end{tabular}


at the neighbourhood and plot level. Six spatial determinants were identified having a significant role at the local level and providing facilities for the neighbourhood (Table 1). Geometrically, there are point factors, line factors and polygon factors. The influence of point factors are discussed with two dimensional concentric buffers. Whereas, influence of line and polygon factors could be explained by three dimensional contours. This study assesses land value with respect to point factors functioning as a magnetic focal point at the city or local level. Six such identified point factors having an impact on land value, including neighbourhood facilities are: (i) airport, (ii) bus stops, (iii) hospitals, (iv) malls, (v) railway station and (vi) schools, which were compared with urban land values for the case of Bhopal.

\section{Land value assessment and results}

Analysis of the relationship between neighbourhood preferences and residential land value was performed in three steps. Published Collector land value was the data source. First, facts regarding land value disparity were observed based on statistical trend assessment of data in the last two decades. Secondary data were validated with the perception of recent residential land buyers by a comparative assessment of the land value dataset. Priorities of buyers were examined through a stratified sample survey of recent buyers in the second step. Descriptive statistics gives a cross-sectional view on market conditions in terms of property and land-value effects. A contour model with 3111 residential locations was prepared in GIS, which also decreased the spatial descriptive behaviour of land value in the third step. The identified point factors were scrutinized with respect to the contour model.

\section{Chronology of residential land value}

Residential land value data since 2011 were collected from the District Collector. This gives land and property values for residential and commercial properties. Land values are given with their respective colony, society or location names in a data sheet under the municipal wards of Bhopal. Land value data of the last two decades were reviewed to assess their spatio-temporal changes. The data revealed that the land value of a particular location changes proportionally independent of any rational or theory. Land values of public non-marketable properties and slums under bridges were also noted. The increase in land value due to proximity of road for commercial and residential land use is the same, whereas the public preference for both is not same. Land speculations due to infrastructure development were not projected. The district collector land value remains same irrespective of influence of identified factor. This suggests that secondary data from the District Collector are different from the ground reality and follow a conventional approach of land-value projections.

Thus, there is a need to review land value data spatially and revisit the facts observed, which are not similar to urban residential land market. Buyers' perceptions towards different factors might play a significant role in land value-related research. Residential land buyers wish to pay an additional amount for the necessary facilities. Therefore identification of factors having an impact on land value and their spatial relation might contribute to land valuation research. A GIS-based approach to prepare a land value contour model has been proposed here with six identified factors that function as neighborhood facilities.

\section{Priority of residential land buyers}

Bhopal Municipal Corporation has been classified into 14 municipal zones. Five recent residential land or property buyers from each zone were surveyed to distinguish their preferences among the six identified factors during land purchase. Their opinions regarding the importance of facilities were grouped in four classes, viz. not important, fairly important, important and very important for the identified factors based on the 'Likert scale'. Percentage frequency distribution for each factor in the four different scales of priority was calculated (Table 2).

All identified facilities were considered important for the selection of residential land in the recent buyers' preferences. Bus stops, hospitals and schools were prime facilities during the selection of residential land, while distance from the airport was least important for the buyers. Other factors were also considered at the time of residential land selection to finalize affordable land value by a buyer. The list of factors might also increase, which has an impact on land value. These factors might vary for different cities; therefore, public and stakeholder consultation should be incorporated for the selection of factors and validation of data before land-value mapping and model preparation.

\section{Land value contour model}

After preparing the city base map, a point-shape file for colonies was created. It had 3111 residential colony points to locate different land parcels in Bhopal. A land value contour elevation was generated with the help of GIS with residential land value colony points. The elevated land value contour presents the variation of residential land value in different locations within the Bhopal municipal area. Land value contour elevation is useful to assess the relationship between the identified factors and their surrounding residential land value. The contour elevation model was prepared in three analytical 
Table 2. Percentage frequency of Buyers' preferences

\begin{tabular}{lcccc}
\hline & \multicolumn{3}{c}{ Factors preferred for residential land selection (\%) } \\
\cline { 2 - 5 } Factors & Very important & Important & Fairly important & Not at all important \\
\hline Airport & 5.71 & 12.86 & 27.14 & 54.29 \\
Bus stops & 28.57 & 32.86 & 34.29 & 4.29 \\
Hospitals & 24.29 & 25.71 & 45.71 & 4.29 \\
Malls & 8.57 & 20.00 & 64.29 & 7.14 \\
Railway station & 15.71 & 22.86 & 47.14 & 14.29 \\
Schools & 20.00 & 42.86 & 35.71 & 1.43 \\
\hline
\end{tabular}

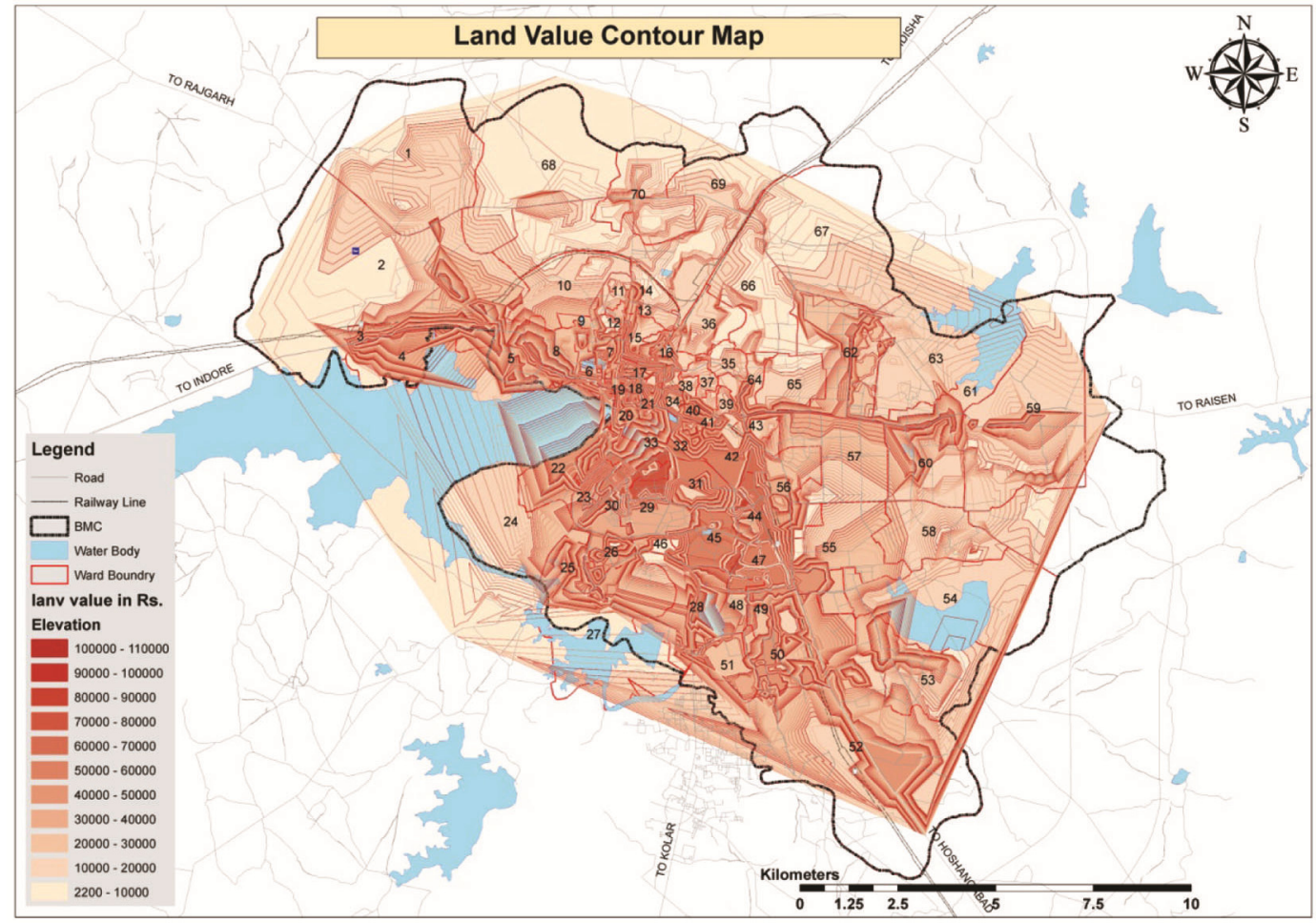

Figure 2. Land value contour for residential land.

stages: (1) create a TIN file in ArcMap; (ii) TIN to shape file in ArcMap and (iii) 3D modelling in ArcScene of GIS. TIN-file was created from a colony point file with the help of a 3D analyst tool which works on the triangular projection system. This could be converted into a contour shape file having a contour line of residential land value. The triangular surface could be developed by converting the TIN file into a shape file using the surface contour tool. Finally, the land value contour model was prepared by inserting base heights of $Z$-value in the layer property (Figure 2).

Land value contour ranges from Rs $2.2 \mathrm{~K}$ per square metre to Rs $110 \mathrm{~K}$ per square metre. Only two colony samples had land value more than Rs $100 \mathrm{~K}$ per square metre. These sample colonies have been proposed for commercial use in the new land-use plan 2031 of the Bhopal development plan. The land value range was grouped into four classes of size Rs $25 \mathrm{~K}$ each. The ele- vated land value contours were vertically divided under the four classes of Rs 0-25 K, Rs $25 \mathrm{~K}-50 \mathrm{~K}$, Rs $50 \mathrm{~K}-$ $75 \mathrm{~K}$ and Rs $75 \mathrm{~K}-100 \mathrm{~K}$ (Figure 3).

Point shape files for identified factors were also prepared. The school shape file had maximum points, while the airport shape file had only one location point. The land value of location points of six factors were represented by contour's elevation. Therefore, high altitude contours present high land value. Therefore, factor points having high residential land value in the surroundings were elevated at higher altitude contour. Each factor point was recognized with its land value contour to classify the samples into classes of Rs 0-25 K, Rs 25-50 K, Rs $50-75 \mathrm{~K}$ and Rs $75-100 \mathrm{~K}$ (Figures 4 and 5). ArcScene application of GIS was useful to perform the exercise of contour modelling and its presentation.

Location points of all factors were classified within these four land-value classes according to the spatial land 


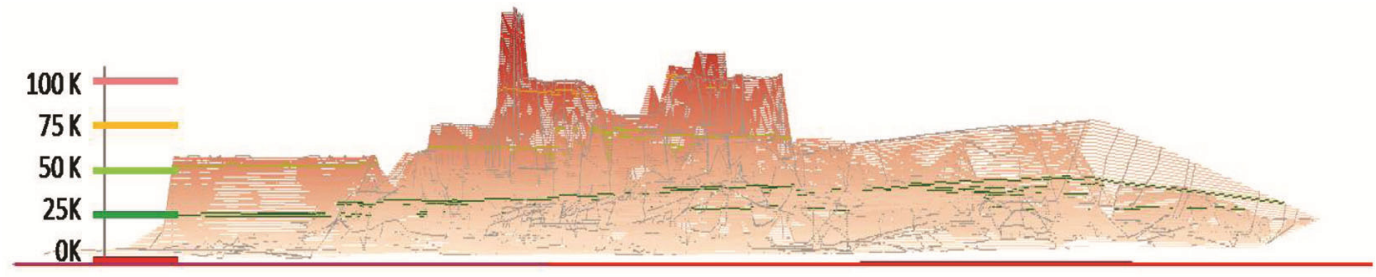

Figure 3. Land value classes for different contour levels.
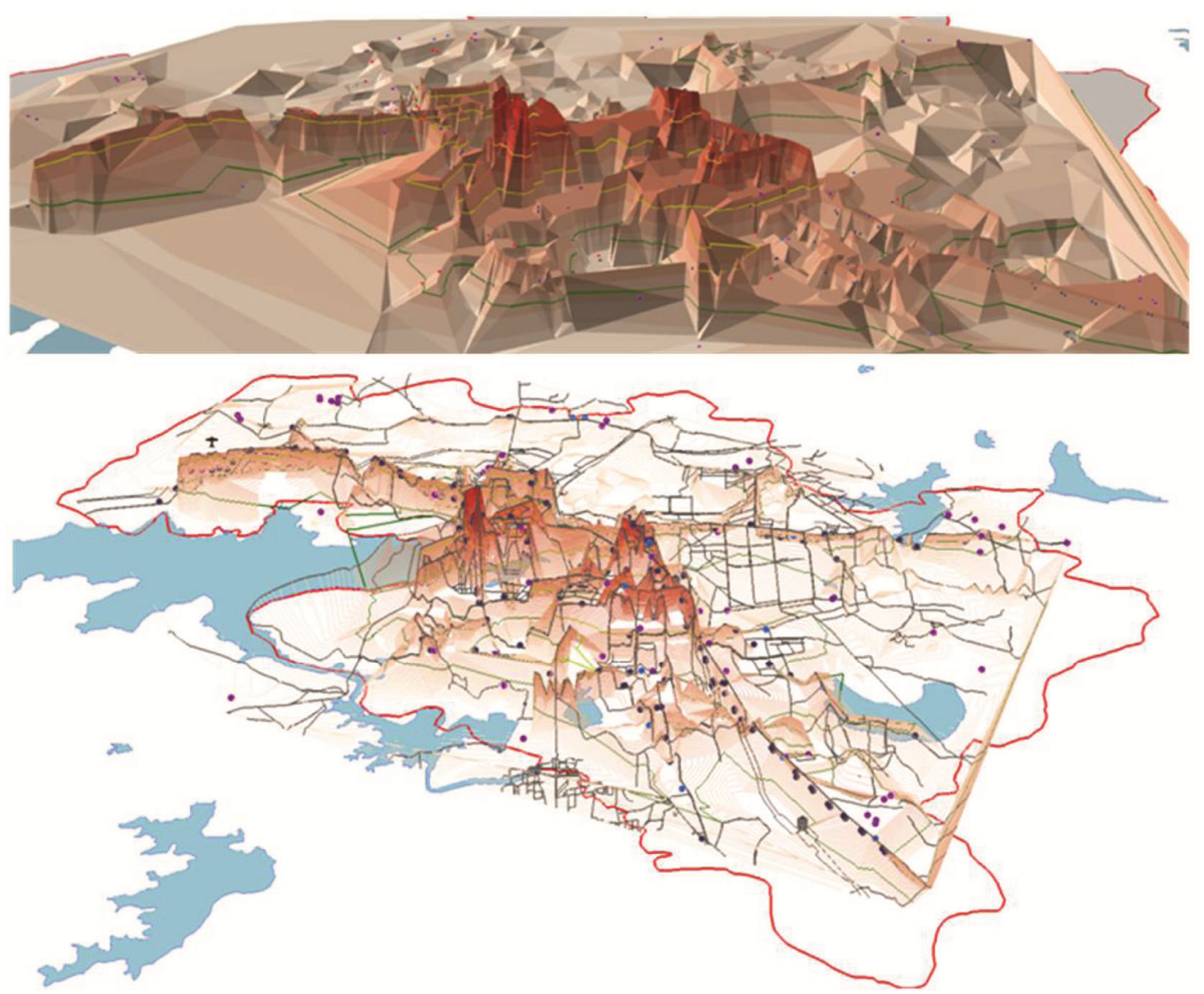

Figure 4. Bird's-eye view of location points of six factors.

value contour. The percentage frequency distribution of factor points was calculated for all four classes (Table 3). The four-classes were assigned weights from 1 to 4 according to the increase in residential land value. Based on percentage frequency and assigned weight, weighted mean values were calculated for each factor (eq. 1).

$$
\mathrm{WM}_{\mathrm{f}}=\left(P_{\mathrm{c} 1} \times 1+P_{\mathrm{c} 2} \times 2+P_{\mathrm{c} 3} \times 3+P_{\mathrm{c} 4} \times 4\right) / 100,
$$

where $\mathrm{WM}_{\mathrm{f}}$ is the weighted mean of a factor and $P_{\mathrm{cn}}$ is the percentage frequency of the $n$th class.

The weighted mean value of a mall was maximum, which suggests that a mall or market place is highly preferred for the selection of residential land. Land value around a mall is comparatively higher than the other factors. Commercial area, convenience shopping and other alternatives could be proposed with a residential project development to attract more buyers. Similarly, willingness to pay was higher for bus stops, as they provide easy access to other places in the city, while it was very low for the airport. The influence zone of airport is beyond the city limit. However, only a fraction of population enjoys its benefit. Other factors could be compared according to their weighted mean value, suggesting the preferences of buyers for residential location selection.

\section{Results and conclusion}

Here we have studied the factors influencing residential land value. We found that people were willing to pay an 


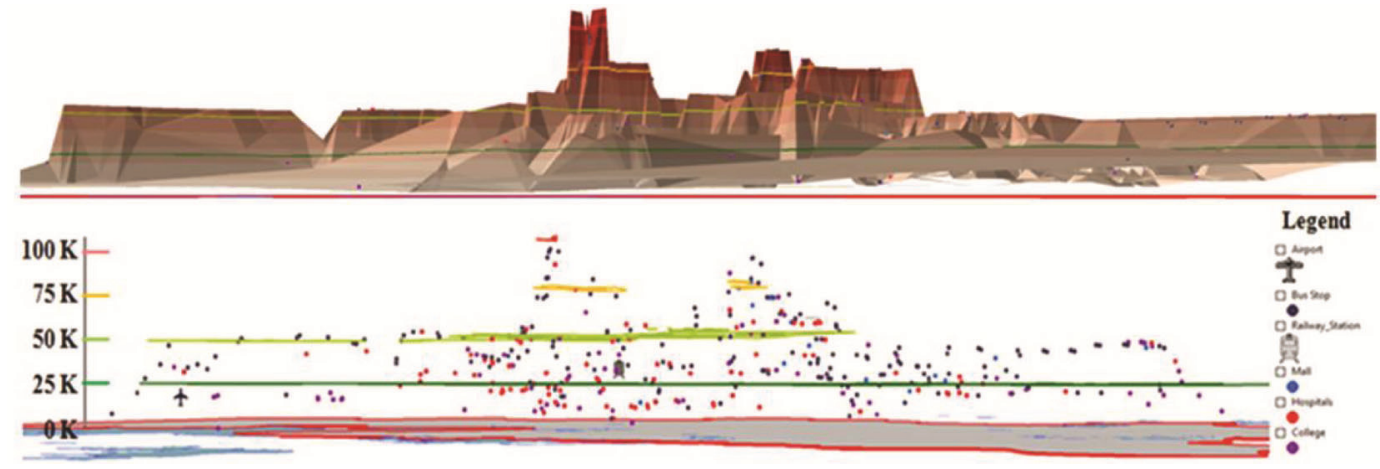

Figure 5. Elevated factor points on land value contour.

Table 3. Weighted mean value of factors

\begin{tabular}{lrrrrrr}
\hline & & \multicolumn{4}{c}{ Percentage frequency distribution } \\
\cline { 3 - 6 } Factors & Sample points & $0-25 \mathrm{~K}$ & $25-50 \mathrm{~K}$ & $50-75 \mathrm{~K}$ & $75-100 \mathrm{~K}$ & Weighted mean \\
\hline Airport & 1 & 100 & 0 & 0 & 0 & 1.00 \\
Bus stops & 185 & 17 & 55 & 22 & 6 & 2.17 \\
Railway station & 4 & 50 & 25 & 25 & 0 & 1.75 \\
Malls & 15 & 13 & 47 & 40 & 0 & 2.27 \\
Hospitals & 11 & 33 & 47 & 18 & 2 & 1.89 \\
Schools & 77 & 53 & 36 & 9 & 1 & 1.56 \\
\hline
\end{tabular}

additional amount for residential land if it had easy and economic access to the neighbourhood facilities. The selection and preference of factors for residential land by buyers were also different. It depended on the buyers' personal requirements and affordability. The development of roads, commercial areas, college or university, access to public transport, provision of basic amenities, social infrastructure, transportation connectivity, environmental quality and recreational facilities were the governing factors for the high residential land value in the cities. The study findings can be discussed by answering the following questions: (i) What are the factors having an impact on land value? (ii) What is the role of the contour model in urban land value assessment? (iii) What is the spatial pattern of residential land value in the urban area of Bhopal city?

The influencing factors of residential land value could be divided into five aspects, i.e. location, transportation, environmental, social and administrative factors with measurable qualitative variables and non-measurable quantitative variables. Thus, selecting the significant factors, which are comparable with the land values, is important in residential land value model-building. The factors selected were facilities like schools, convenience of bus stops, access to malls, hospitals, distance to railway station and airport. These factors have significant impact on land value in residential colonies.

The present study provides insights into the spatial structure of land value using the contour model. The model has three-dimensional behaviour which presents the elevated surface morphology for a dataset. A contour model could be prepared in a GIS platform with land value dataset. Comparative spatial assessment for land value could be made with reference to the location of the neighbourhood facilities and other factors. It was observed that land values show a discrepancy within one municipal zone and between zones, with most of the expensive land parcels in the city centre. The higher altitude of land value contour along the arterial and subarterial roads suggests that the city has concentric growth in urban centres, while it follows a radial pattern of growth in suburban and peri-urban areas. Repeated redevelopment in the city core increases land value exponentially, as it provides new opportunities each time. One could also easily find economic land parcels whose land values were less than those of some parcels in peripheral areas of the city, reflecting the variation in property values in the central town. The contour model could portrait well the uneven distribution of land values in different locations of a city. The elevated factors on contour morphology could be compared with factor density per unit area. This comparative study of land value and geographical location of factors might be mapped and a numeric regression model could also be prepared. The proposed contour model is useful to estimate the land value of a location based on accessibility to neighbourhood facilities.

Spatial variables, especially distance to the city centre, were also important in shaping land-value morphology. The key drivers for growth of Bhopal city are its rich historical background, new state capital and industrial 
establishment. The central retail market and service sectors have highest buyer preference. Residential land parcels are more expensive in the west and southeast than in north Bhopal. Land value is very high in close proximity of a mall, while least near an airport. Comparative study of land value of a location and its accessibility to different facilities would be useful for an explanation of spatial land-value patterns. It will also be beneficial for investors, planners, residential developers and policy-makers in the decision-making processes.

Lack of a large, complete, accurate and representative dataset is one of the major limitations of the contour model. Bhopal functions as an educational hub and commercial centre for its region. There are many focal points within the city limits that attract people as potential residential land. It was observed that land near convenience shopping had higher value than other areas. The spatial representation of land value through the contour model highlights Bhopal as a polycentric city. The city model does not perfectly fit the concentric theory of bid rent. More accurate and dense land-value data points and information are required for the preparation of land-value morphology. Land value has a dynamic characteristic. The comprehensive-land value variation is not only from spatial characteristics, but also justify the temporal changes. Authorities should be equipped with advanced GIS software and other technical aids to improve the land valuation method. The present conventional approach of valuation adopted by the district administration ignores the land-value impact factors. GIS-based tools could improve the accuracy of measurement and efficiently accomplished land valuation. Moreover, GIS capabilities not only facilitate the organization and management of geographic data, but also enable researchers to take full advantage of location information contained in the databases to support the application of spatial statistical and spatial econometric tools. A more accurate approach of land valuation is needed to increase government revenue and the increased accessibility to the citizens.

1. Nichols, J. B., Oliner, S. D. and Mulhall, M. R., Commercial and residential land prices across the United States. Federal Reserve Board, Washington, DC, USA, 2010.

2. The Planning Commission of India, The challenges of urbanization in India. Appraisal Report, Delhi, 2011.

3. Topcu, M. and Kubat, A. S., The analysis of urban features that afftect land values in residential areas. In Seventh International Space Syntax Symposium, Stockholm, Sweden, 2009, pp. 26:1-26:9.

4. Lee, Y. P., Determinants of Singapore residential land value, Report, Massachusetts Institute of Technology, Singapore, 1996.

5. Bhopal City Development Plan, Mehta and Associates, Bhopal, 2008 .

6. Grimes, A. and Liang, Y., Spatial determinants of land prices in Auckland: does the metropolitan urban limit have an effect? Motu Economic and Public Policy Research, New Zealand, 2007.

7. Saefuddin, A., Widyaningsih, Y., Ginting, A. and Mamat, M., Land price model considering spatial factors. Asian J. Math. Stat., 2012, 5(4), 132-141.
8. Emoh, F. I., Oni, A. O. and Egolum, C. C., Prioritizing residential land value determinants in Onitsha, Nigeria. Int. J. Acad. Res. Bus. Soc. Sci., 2013, 3(3), 201-213.

9. Dutt, A. K. and Khan, A. A. M., Multi-peaked urban land values: city of Akron Case. Ohio J. Sci., 1982, 82(3), 114-119.

10. Kivell, P., Land and the City: Pattern and Process of Urban Change, Routledge, Wuhan, China, 1993.

11. Adams, D., Urban Planning and the Development Process, Routledge Taylor \& Francis Group, London, 1994.

12. Phe, H. H. and Wakely, P., Status, quality and the other trade-off: towards a new theory of urban residential location. Urban Stud., 2000, 37(1), 7-35.

13. Ai, P., Residential land value modelling: case study of Hankou, China. International Institute for Geo-information Science and Earth Observation, Urban Planning and Land Administration, The Nitherlands, 2005.

14. Yeates, M. H. and Garner, B. J., The North American City, Harper Collins, New York, 1971.

15. Han, S. S. and Basuki, A., The spatial pattern of land values in Jakarta. Urban Stud., 2001, 38, 1841-1857.

16. Miller, N. G. and Geltner, D. M., Real Estate Principles for the New Economy, South-Western Education Pub., Cincinnati, 2004.

17. Ogbuefi, J. and Egbenta, R., Relationship between transport services and property values in Enugu, Nigeria. J. Sci. Technol. Res., 2002, 1(1), 94-100.

18. Udo, G. and Egbenta, R., Effect of domestic waste dumpsites on rental values of residential properties in Enugu. Nigerian J. Dev. Stud., 2007, 6(1), 79-97.

19. Kauko, T., Residential property value and locational externalities - on the complementarity and substitutability of approaches. J. Property Invest. Finan., 2003, 21(3), 250-270.

20. Olayiwola, L., Adeleye, O. and Oduwaye, A., Spatial variation in residential land value determinants in Lagos, Nigeria. In Fifth FIG Regional Conference, Accra, Ghana, 2006.

21. Morandé, F., Petermann, A. and Vargas, M., Determinants of vacant urban land evidence from Santiago of Chile, Chile. J. Real Estate Finance Econ., 2008, 40(2), 188-202.

22. Tamba, V., Kabba, S. and Li, J., Determinants of urban land price in freetown, Sierra Leone. J. Am. Sci., 2011, 7(2), 213-223.

23. Uju, I. V. and Iyanda, S. T., Comparative analysis of the determinants of residential land values. Chin. Bus. Rev., 2012, 11(2), 187-192.

24. Dowall, D. E. and Monkkonen, P., Chennai Urban Land Market Assessment, University of California, Berkeley, 2007.

25. Oduwaye, L., Spatial variations of values of residential land use in Lagos metropolis. Int. Multi-Discip. J. Ethiopia, 2009, 3(2), 381403 .

26. Bhargava, A., Determinants of property values, Jaipur city. Int. J. Sci. Res. Publ., 2013, 3(9), 1-15.

27. Eckert, J. K., Property Appraisal and Assessment Administration (First edn), International Association of Assessing Officers, Chicago, USA, 1990.

28. Lochl, M. A., Modeling hedonic residential rents for land use and transport simulation while considering spatial effects. J. Transp. Land Use, 2010, 3(2), 39-63.

29. Goffette-Nagot, F., Reginster, I. and Thomas, I., A spatial analysis of residential land prices in Belgium: accessibility, linguistic border and environmental amenities, Belgium. Reg. Stud., 2011, 45(9), 1253-1268.

Received 3 May 2020; revised accepted 4 July 2020

doi: $10.18520 / \mathrm{cs} / \mathrm{v} 119 / \mathrm{i} 6 / 1001-1009$ 